\title{
Performance of an Integrated Adsorption- Enhanced Glycerol Supercritical Water Reforming and Pressurized SOFC System
}

\author{
Yaneeporn Patcharavorachot ${ }^{1}{ }^{*}$, Worarat Rattanachai ${ }^{1}$, Dang Saebea ${ }^{2}$, Suthida Authayanun ${ }^{3}$, \\ and Amornchai Arpornwichanop ${ }^{4}$
}

\begin{abstract}
Glycerol supercritical water reforming is a promising process for hydrogen production. The hydrogen product has high pressure and temperature and thus, it can be used as fuel in pressurized solid oxide fuel cells (SOFC). However, the synthesis gas obtained from reforming process contains high amount of $\mathrm{CO}_{2}$ and this leads to the deterioration of SOFC performance. Consequently, the adsorption process is used to remove $\mathrm{CO}_{2}$ from the synthesis gas before feeding into SOFCs. This work aimed to develop models of an integrated system of adsorption-enhanced glycerol supercritical water reforming process and pressurized SOFC. The AspenPlus ${ }^{\mathrm{TM}}$ simulation software was used to calculate the equilibrium compositions of the products from reforming process by the minimization of Gibbs free energy method. The SOFC performance can be computed by electrochemical equations taking into account three voltage losses (activation, ohmic and concentration losses). Effect of operating conditions of SOFC (temperature, pressure and current density) was examined to identify the optimal operating condition. The simulation results indicated that the optimal conditions for SOFC are temperature of $900{ }^{\circ} \mathrm{C}$, pressure of $4 \mathrm{~atm}$ and current density of $10,000 \mathrm{~A} / \mathrm{m}^{2}$. The glycerol reformer which is operated at temperature of $800{ }^{\circ} \mathrm{C}$, pressure of $240 \mathrm{~atm}$ and steam to glycerol molar ratio of 10 can provide the hydrogen product of $87 \%$ (dry basis). When the synthesis gas is fed into SOFC operated under the optimal condition, it was found that the integrated system can be achieved the SOFC efficiency of $71.56 \%$.
\end{abstract}

Keywords-Glycerol, Performance analysis, Solid oxide fuel cell, supercritical water.

\section{INTRODUCTION}

Hydrogen $\left(\mathrm{H}_{2}\right)$ is a useful substance that can use in many industries; for example, $49 \%$ of hydrogen is used in ammonia production and $37 \%$ of hydrogen is used for refining and upgrading purpose in petroleum and petrochemical industry [1]. More significantly, hydrogen is sustainable energy source for fuel in recent year. It can be used as a fuel for combustion engines or fuel cells to produce power energy without carbon emissions [2].

\footnotetext{
${ }^{1}$ Department of Chemical Engineering, Faculty of Engineering, King Mongkut's Institute of Technology Ladkrabang, Bangkok 10520, Thailand

${ }^{2}$ Department of Chemical Engineering, Faculty of Engineering, Burapha University, Chonburi 20131, Thailand

${ }^{3}$ Department of Chemical Engineering, Faculty of Engineering, Srinakharinwirot University, Nakhon Nayok 26120, Thailand

${ }^{4}$ Computational Process Engineering Research Unit, Department of Chemical Engineering, Faculty of Engineering, Chulalongkorn University, Bangkok, 10330, Thailand
}

Glycerol is the main by-product of the biodiesel production by transesterification of vegetable oils [3]. Due to the increase in biodiesel production, crude glycerol, consisting of glycerol, methanol/ethanol, soap, catalyst, and organic matter, has led to increase simultaneously while its prices are low [4]. Although, glycerol can be used in many industries, e.g., cosmetics, pharmaceutics food, and polymer, it needs to be in a high purity condition which causes high cost of production. One of attractive ways to add value of glycerol is the use of glycerol for hydrogen production. The usage of crude glycerol has been received much interest since both glycerol and methanol/ethanol can be converted into hydrogen via reforming process.

In general, there are three main reforming processes for hydrogen production, i.e., steam reforming, partial oxidation and autothermal reforming. Among these processes, steam reforming is well-known established process and provides the highest hydrogen yield [5]. However, due to its endothermic reaction, the external heat is highly required. Recently, there are many researchers focused on glycerol supercritical water reforming [4,6-10]. Since supercritical water has advantage properties such as a low dielectric constant that affects to the solubility of components in supercritical water. The solubilize capacity for organic compounds increase and inorganic compounds decrease and thus, reaction time and the requirement of energy in reactor are decrease [3,9]. Moreover, supercritical water is not only a processing medium but also a catalyst in reforming reaction [3]. Interestingly, the synthesis gas obtained from supercritical water reforming has high pressure and thus, it is easily and directly to store. Furthermore, it can be used as fuel for pressurized solid oxide fuel cell (SOFC) without the need of the external gas compression. The pressurize SOFC is referred to the SOFC operated under higher atmospheric pressure

However, the gas product from the glycerol reformer always contains highly content of $\mathrm{CO}_{2}$. This indicates that the hydrogen concentration is lower and this may cause the deterioration of SOFC performance. Therefore, the $\mathrm{CO}_{2}$ removal process should be included in the reforming process to purify hydrogen. Among various $\mathrm{CO}_{2}$ removal processes (e.g. pressure swing adsorption, temperature-swing adsorption, physical absorption and chemical absorption process), adsorption process by $\mathrm{CO}_{2}$ adsorbent is an attractive process and commonly applied in reforming process. Calcium oxide $(\mathrm{CaO})$ can be widely used as a $\mathrm{CO}_{2}$ adsorbent because it is low 
price, easy to find and considered as high adsorption ability [11]. The adsorption-enhanced reforming process in which adsorbents are added into the reformer to enhance the reactions and realize in situ $\mathrm{CO}_{2}$ separation is focused in this work.

This work aims to investigate the performance of an integrated system of adsorption-enhanced glycerol supercritical water reforming process and pressurized SOFC in the thermodynamics aspects by using AspenPlus ${ }^{\mathrm{TM}}$. Effect of operating conditions of reformer (temperature, pressure and steam to glycerol molar ratio) and SOFC (temperature, pressure and current density) is examined to identify the optimal operating condition.

\section{PROCESS DESCRIPTION}

Fig. 1 presents the schematic of an integrated system of adsorption-enhanced glycerol supercritical water reforming and pressurized SOFC designed in the Aspen Plus flowsheet. First, crude glycerol and supercritical water is fed into mixer. The mixture stream is fed through heater to reach the operating temperature. Then, the mixture stream is fed to reformer. In this case, calcium carbonate $(\mathrm{CaO})$ as a $\mathrm{CO}_{2}$ adsorbent is added into reformer and thus, reforming reaction and $\mathrm{CO}_{2}$ separation occur simultaneously. After that, $\mathrm{CaCO}_{3}$ generated from $\mathrm{CO}_{2}$ adsorption reaction is introduced into regenerator (REGEN) to revive by heat. Specification details of each unit model in the processes are shown in Table 1. The possible reactions in glycerol supercritical water reforming with in situ $\mathrm{CO}_{2}$ removal processes are glycerol reforming (Eq. (1)), glycerol decomposition (Eq. (2)), water gas shift (Eq. (3)), methanol reforming (Eq. (4)), methanol decomposition (Eq. (5)), methane formation (Eq. (6)) and $\mathrm{CO}_{2}$ adsorption (Eq. (7)).

$\mathrm{C}_{3} \mathrm{H}_{8} \mathrm{O}_{3}+3 \mathrm{H}_{2} \mathrm{O} \leftrightarrow 3 \mathrm{CO}_{2}+7 \mathrm{H}_{2}$

$\mathrm{C}_{3} \mathrm{H}_{8} \mathrm{O}_{3} \leftrightarrow 3 \mathrm{CO}+4 \mathrm{H}_{2}$

$\mathrm{CO}+\mathrm{H}_{2} \mathrm{O} \leftrightarrow \mathrm{CO}_{2}+\mathrm{H}_{2}$
$\mathrm{CH}_{3} \mathrm{OH}+\mathrm{H}_{2} \mathrm{O} \leftrightarrow \mathrm{CO}_{2}+3 \mathrm{H}_{2}$

$\mathrm{CH}_{3} \mathrm{OH} \leftrightarrow \mathrm{CO}+2 \mathrm{H}_{2}$

$\mathrm{CO}+3 \mathrm{H}_{2} \leftrightarrow \mathrm{CH}_{4}+\mathrm{H}_{2} \mathrm{O}$

$\mathrm{CaO}+\mathrm{CO}_{2} \leftrightarrow \mathrm{CaCO}_{3}$

TABLE I:

SPECIFICATION DETAILS OF EACH UNIT MODEL IN GLYCEROL SUPERCRITICAL WATER REFORMING PROCESS

\begin{tabular}{|l|l|l|}
\hline Name & Unit Model & Standard Operating Conditions \\
\hline MIXER & Mixer & - \\
\hline HEATER & Heater & $800{ }^{\circ} \mathrm{C}$ \\
\hline REFORMER & RGibbs & $800{ }^{\circ} \mathrm{C}$, \\
& & 240 atm \\
\hline ADSORBER & RGibbs & $600{ }^{\circ} \mathrm{C}$, \\
& & 5 atm \\
\hline REGEN & RGibbs & $850{ }^{\circ} \mathrm{C}$, \\
& & 1 atm \\
\hline HEATER2 & Heater & $800{ }^{\circ} \mathrm{C}$ \\
\hline ANODE & RGibbs & $800{ }^{\circ} \mathrm{C}$, \\
& & 4 atm \\
& & $4,000 \mathrm{~A} / \mathrm{m}^{2}$ \\
\hline COMPR1 & Compr & $800{ }^{\circ} \mathrm{C}$ \\
\hline HEATER3 & Heater & Mole fraction of oxygen $=0.21$ \\
\hline CATHODE & Sep & \\
\hline
\end{tabular}

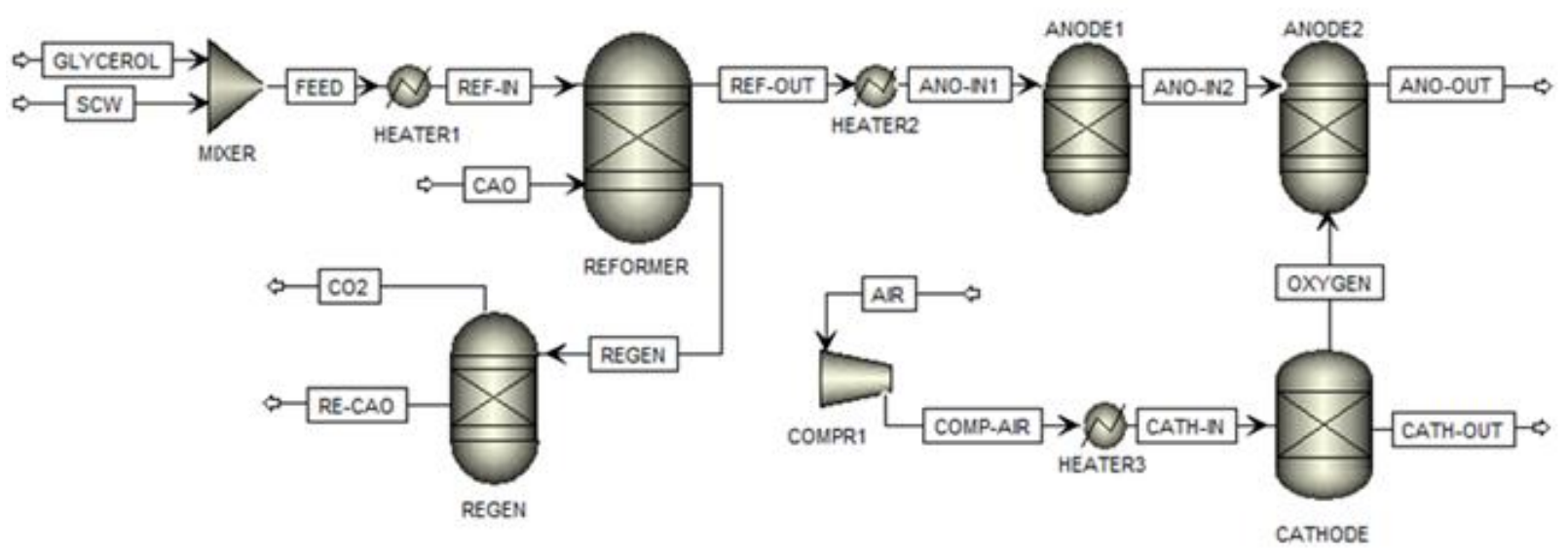

Fig. 1: A schematic of adsorption-enhanced glycerol supercritical water reforming integrated with pressurized SOFC 


\section{SOFC MODEL}

The compositions of hydrogen and oxygen are used to determine the performance of SOFC (e.g., cell voltage, power density and cell efficiency) through the detailed electrochemical model. The open-circuit voltage which is the maximum voltage of SOFC can be determined by the Nernst equation. However, the operating cell voltage is always lower than open-circuit voltage since there are three main voltage losses occurred in real operation: activation loss, ohmic loss and (3) concentration loss. The electrochemical equations of SOFC used in this study were reported in our previous work [12].

\section{SOLUTION APPROACH}

In this study, the thermodynamic calculation is performed by using AspenPlus ${ }^{\mathrm{TM}}$. The model is performed based on the following assumptions: (1) isothermal and steady state operation are considered; (2) pressure drops are neglected; (3) reforming and shift reactions reach chemical equilibrium; and (4) only $\mathrm{H}_{2}$ is electrochemically oxidized. Firstly, for given operating conditions of reformer, the equilibrium compositions in the reforming process can be determined by using the total Gibbs free energy minimization method. The equation of state used in this calculation was based on the Soave-RedlichKwong (SRK). The molar flow rate of $\mathrm{CH}_{4}\left(n_{\mathrm{CH} 4}\right), \mathrm{CO}\left(n_{\mathrm{CO}}\right)$ and $\mathrm{H}_{2}\left(n_{\mathrm{H} 2}\right)$ obtained from reforming process is further used as the input parameters for the SOFC calculation. It is noted that the electrochemical equations, as described in Section 3, is performed by a calculator block in the Aspen Plus flowsheet. When the operating conditions of SOFC (temperature, pressure and current density $\left.\left(i_{\mathrm{SOFC}}\right)\right)$ and physical parameters of cell components are specified, the cell voltage $(V)$, power density $\left(P_{\mathrm{w}}\right)$ and SOFC electrical efficiency $\left(\varepsilon_{\mathrm{SOFC}}\right)$ can be calculated as follows:

$$
\varepsilon_{\mathrm{SOFC}}=\frac{P_{w}=i_{\mathrm{SOFC}} V}{n_{\mathrm{CH}_{4}} L H V_{\mathrm{CH}_{4}}+n_{\mathrm{H}_{2}} L H V_{\mathrm{H}_{2}}+n_{\mathrm{CO}} L H V_{\mathrm{CO}}} \times 100 \%
$$

\section{RESULTS AND DISCUSSION}

The standard operating conditions used in this study are shown in Table 1. The inlet flow rate of supercritical water and glycerol is $10 \mathrm{kmol} / \mathrm{h}$ and $1.25 \mathrm{kmol} / \mathrm{h}$, respectively. Thus, supercritical water to glycerol $(\mathrm{S} / \mathrm{G})$ molar ratio is 10 . For adsorption process, $\mathrm{CaO}$ feed rate of $2 \mathrm{kmol} / \mathrm{h}$ is introduced to the reformer. Under these operating conditions, the gas product obtained from glycerol supercritical water reforming process consists of $87 \% \mathrm{H}_{2}, 0.7 \% \mathrm{CO}, 0.3 \% \mathrm{CO}_{2}$ and $12 \%$ $\mathrm{CH}_{4}$ (dry basis). Then, the performance of an integrated adsorption-enhanced glycerol supercritical water reforming and pressurized SOFC system is investigated with respect to the impact of operating conditions, i.e., temperature, pressure and current density.

\section{A. Effect of SOFC Temperature}

Fig. 2 presents the SOFC efficiency as a function of SOFC temperature $\left(800-1000^{\circ} \mathrm{C}\right)$. When the SOFC is operated at constant pressure of $4 \mathrm{~atm}$ and current density of $5,000 \mathrm{~A} / \mathrm{m}^{2}$, it is found that increasing SOFC temperature can achieve higher cell voltage. Increase in operating temperature of SOFC increases the rate of electrochemical reaction; the consumption of hydrogen is higher and thus, the open-circuit voltage also increases. Considering cell voltage losses, it is also found that the increased operating temperature causes a decrease in voltage losses, particularly in ohmic and activation losses. Therefore, the efficiencies of SOFC system are increased with increasing temperature, as seen in Fig. 2.

\section{B. Effect of SOFC Pressure}

In order to study the pressure effect, SOFC temperature and current density are kept constant as $1,000{ }^{\circ} \mathrm{C}$ and 5,000 $\mathrm{A} / \mathrm{m}^{2}$, respectively. In general, the SOFC operated at high pressure can provide higher cell voltage since higher partial pressure of $\mathrm{H}_{2}$ can increase an open-circuit voltage. In addition, at high pressure operation, fuel and oxidant gases can easily diffuse to the reaction site and thus, the concentration loss is decreased. When cell voltage can be achieved, power density and SOFC efficiency are higher. However, in this simulation, it is found that increasing SOFC pressure in range of 4-8 atm has a slight influence to cell performance (Fig. 3).

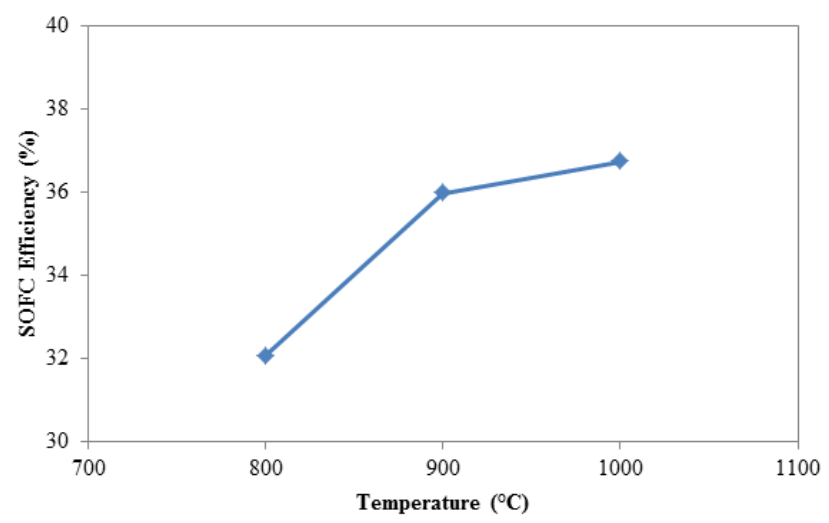

Fig. 2: Effect of temperature on SOFC electrical efficiency.

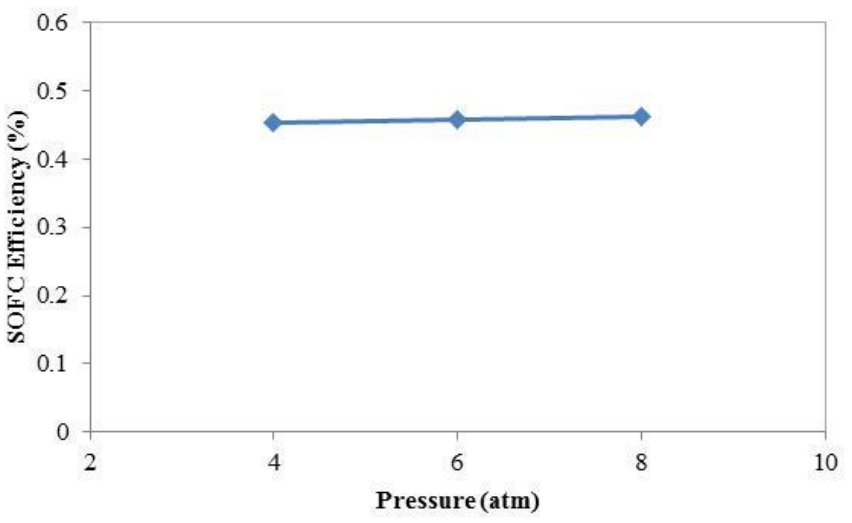

Fig. 2: Effect of pressure on SOFC electrical efficiency. 


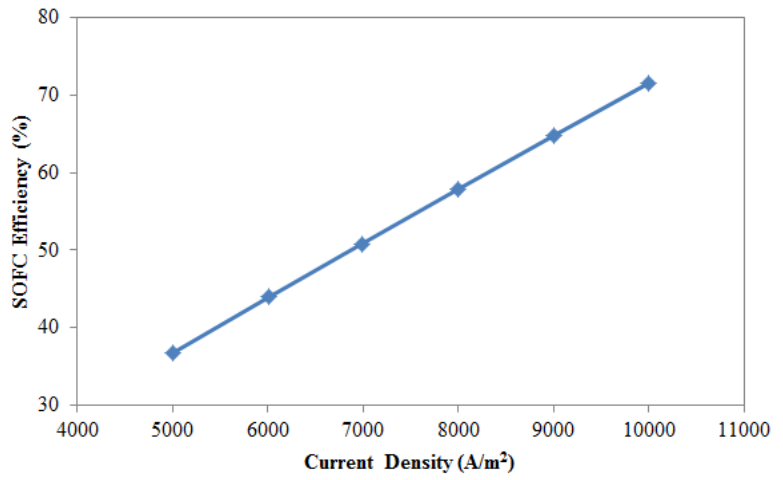

Fig.4: Effect of current density on SOFC electrical efficiency.

\section{Effect of Current Density}

Finally, the effect of current density on SOFC efficiency is further investigated, as shown in Fig. 4. The current densities are varied in the range of 5,000 to $10,000 \mathrm{~A} / \mathrm{m}^{2}$ whereas SOFC temperature and pressure are kept constant as $1,000{ }^{\circ} \mathrm{C}$ and 4 atm, respectively. From the simulation result, it can be found that the cell voltage decreases strongly with increasing current density. This is because higher current density leads to increases in all voltage losses. Unlike cell voltage, the power density can be increased when the current density is higher and thus, the SOFC efficiency can be improved.

\section{CONCLUSIONS}

An integrated system of adsorption-enhanced glycerol supercritical water reforming and pressurized SOFC is proposed in this study. An integrated system is designed and developed via the Aspen Plus simulator. Among various parameters considered in the SOFC operation, it is found that the SOFC temperature and current density are significant parameters on system performance. Higher SOFC temperature and current density cause a considerable higher SOFC efficiency. The simulation results indicate that the optimal operating conditions of the SOFC are $900^{\circ} \mathrm{C}, 4$ atm and current density of $10,000 \mathrm{~A} / \mathrm{m}^{2}$, respectively. The integrated system can provide the SOFC electrical efficiency of $71.56 \%$.

\section{ACKNOWLEDGMENT}

The support from King Mongkut's Institute of Technology Ladkrabang and the Thailand Research Fund is gratefully acknowledged.

\section{REFERENCES}

[1] R.G. Siddharth, "Hydrogen Production by Supercritical Water Reforming by Bio-oil Components," M.S. thesis, Auburn University, 2012.

[2] H.M. Wang, "Experimental studies on hydrogen generation by methane autothermal reforming over nickel-based catalyst," Journal of Power Sources, vol. 177, pp. 506-511, 2008. http://dx.doi.org/10.1016/j.jpowsour.2007.10.083

[3] F.J.G. Ortiz, P. Ollero, A. Serrera, and S. Galera, "Experimental study of the supercritical water reforming of glycerol without the addition of a catalyst," Energy, vol. 56, pp.193-206, 2013. http://dx.doi.org/10.1016/j.energy.2013.04.046

[4] E. Markocic, B. Kramberger, J.G. van Bennekom, H.J. Heeres, J. Vos, Z. Knez, "Glycerol reforming in supercritical water; a short review," Renewable and Sustainable Energy Reviews, vol. 23, pp. 30 - 33, 2013. http://dx.doi.org/10.1016/j.rser.2013.02.046

[5] H. Chen, T. Zhang, B. Dou, V. Dupont, P. Williams, M. Ghadiri, and Y. Ding, "Thermodynamic analyses of adsorption-enhanced steam reforming of glycerol for hydrogen production," International Journal of Hydrogen Energy, vol. 34, pp. 7208 - 7222, 2009. http://dx.doi.org/10.1016/j.ijhydene.2009.06.070

[6] F.J.G. Ortiz, P. Ollero, A. Serrera, and S. Galera, "Thermodynamic study of the supercritical water reforming of glycerol," International Journal of Hydrogen Energy, vol. 36, pp. 8994 - 9013, 2011. http://dx.doi.org/10.1016/j.ijhydene.2011.04.095

[7] T. Pairojpiriyakul, E. Croiset, W. Kiatkittipong, K. Kiatkittipong, A. Arpornwichanop, and S. Assabumrungrat, "Hydrogen production from catalytic supercritical water reforming of glycerol with cobalt-based catalysts," International Journal of Hydrogen Energy, vol. 38, pp. 4368 - 4379, 2013.

http://dx.doi.org/10.1016/j.ijhydene.2013.01.169

[8] J.G. van Bennakom, R.H. Venderbosch, D. Assink, and H.J. Heeres, "Reforming of methanol and glycerol in supercritical water," Journal of Supercritical Fluids, vol. 58, pp. 99 - 113, 2011. http://dx.doi.org/10.1016/j.supflu.2011.05.005

[9] F.J.G. Ortiz, P. Ollero, A. Serrera, and S. Galera, "Optimization of power and hydrogen production from glycerol by supercritical water reforming," Chemical Engineering Journal, vol. 218, pp. 309 - 318, 2013. http://dx.doi.org/10.1016/j.cej.2012.12.035

[10] Y. Patcharavorachot, N. Chery-rod, S. Nudchapong, S. Authayanun, and A. Arpornwichanop, "Hydrogen Production from Glycerol Steam Reforming in Supercritical Water with $\mathrm{CO}_{2}$ Absorption Unit." Chemical Engineering Transactions, vol. 39, pp. 349-354, 2014.

[11] A.M. Roger, " $\mathrm{CO}_{2}$ Capture Materials for Sorption Enhanced Steam Reforming," Ph.D. dissertation, The university of Leeds and Roger Axel Molinder, 2012.

[12] Y. Patcharavorachot, A. Arpornwichanop, and A. Chuachuensuk, "Electrochemical study of a planar solid oxide fuel cell: Role of support structures," Journal of Power Sources, vol. 177, pp. 254-261, 2008. http://dx.doi.org/10.1016/j.jpowsour.2007.11.079 